\title{
Viral effects on bacterial community composition in marine plankton microcosms
}

\author{
Michael S. Schwalbach*, Ian Hewson, Jed A. Fuhrman \\ Department of Biological Sciences and Wrigley Institute for Marine Studies, University of Southern California, Los Angeles, \\ California 90089-0371, USA
}

\begin{abstract}
Recent theory suggests that viruses influence bacterial community composition by killing the winners of resource competition. We tested aspects of this theory by growing natural marine bacteria communities in seawater microcosms that had either significantly reduced or increased virus abundances and monitoring changes in the bacterial communities. Bacterial community composition was assayed by 2 whole-community fingerprinting techniques, terminal restriction fragment length polymorphisms (TRFLP) and automated ribosomal intergenic spacer analysis (ARISA), at the beginning and end of experiments to examine the effect of changes in viral abundance on bacterial community composition. Our results suggest that changes in viral abundances have mixed effects on microbial community fingerprints. Modest, but statistically significant, changes in community fingerprints were seen when most viruses were removed by filtration and bacteria subsequently grown over $5 \mathrm{~d}$ compared to growth at normal virus density. There were no significant differences between community fingerprints from microcosms grown with a normal versus 3-fold density of viruses over $2 \mathrm{~d}$ (possibly because of slow growth rates); however, significant changes occurred over time, regardless of virus abundance, suggesting that manipulation and containment alone had a strong influence on community fingerprints, which may have masked some virus effects. Also, moderate natural variation in composition between replicate microcosms made it difficult to distinguish statistically significant virus effects. Given that relatively few significant changes were apparent in community fingerprints between virus treatments at the end of our experiments, it is possible that current models of virus infection and the possible roles of viruses in controlling community composition need re-evaluation. The persistence of high viral abundance and apparent high turnover, in concert with our results, suggests that viruses and their hosts may have a more stable coexistence than is now currently thought. However, it is possible that the modest effects of viral infection observed in this short-term study could be significantly amplified over longer time-scales of weeks or months, resulting in viruses having a more substantial influence on bacterial community composition.
\end{abstract}

KEY WORDS: Marine bacteria · Community composition · Plankton · Viruses · Terminal restriction fragment polymorphism - Automated ribosomal intergenic spacer analysis · Bacteriophage

Resale or republication not permitted without written consent of the publisher

\section{INTRODUCTION}

Viruses have been shown to account for approximately 10 to $40 \%$ of bacterial mortality in marine and freshwater bacterioplankton (Fuhrman \& Noble 1995, Hennes \& Simon 1995), and at times cause greater mortality than grazers (Weinbauer \& Peduzzi 1995, Steward et al. 1996, Guixa-Boixereu et al. 1999). Previous experiments have demonstrated that viral infection does not have an equal effect on all species in a bacterial community, but rather that certain bacteria (lysed cells) in the community are adversely affected by the presence of viruses, while other bacteria (non-lysed cells) indirectly benefit from the presence of viruses through the utilization of highly labile dissolved organic carbon (DOC) released from recently lysed cells (Fuhrman 1992, Gobler et al. 1997, Bratbak et al. 1998, Middleboe \& Lyck 2002). However, it is currently 
unknown which members of bacterial communities are infected and lysed by viruses and which benefit indirectly from the presence of viruses. It is believed that the observed non-uniform response of bacterial communities to viral infection is partially due to the mechanisms by which viruses replicate.

Viral infection is a density-dependent process, and relies upon the availability of a suitable host (Moebus 1996, Wommack \& Colwell 2000). Since viruses have no active form of motility, their host must be abundant enough to be encountered via passive diffusion. Bacteria are the most abundant cellular organism in seawater, which is one reason why it is presumed that the majority of viruses in seawater frequently encounter and infect bacteria (Proctor \& Fuhrman 1990, Bratbak et al. 1994). Based on the assumptions that: (1) viruses need a specific and abundant host to maintain their high densities in seawater, and (2) viral infection rate scales proportionally with an individual host's abundance, models have been constructed that examine the effect of marine viruses on bacterial communities (Bratbak et al. 1996, Thingstad \& Lignell 1997, Thingstad 2000). These models have led to the development of a 'phage kills winner' theory, which hypothesizes that diversity levels in bacterial communities are maintained, in part, by viruses killing the winner of interspecific resource competition. Thus, viral infection and resource competition would have opposing effects on bacterial communities, with interspecific competition lowering community diversity and viral infection increasing community diversity (Fuhrman \& Suttle 1993).

The 'phage kills winner' theory has been partially tested using bacterial populations grown in chemostats (Lenski 1988, Bohannan \& Lenski 2000, Middleboe et al. 2001), with one study examining the effect of viral infection on freshwater bacterial community composition using fluorescent in situ hybridization (Šimek et al. 2001). In addition to these studies, Hennes et al. (1995) used fluorescently labeled viruses to demonstrate that viruses were capable of controlling the concentration of known host bacteria added to natural samples; however, how these results and chemostat studies scale to complex natural communities remains unclear. Fuhrman \& Schwalbach (2003) tested the 'phage kills winner' theory in a natural sample by controlling viral abundances in marine microcosms and observing the resulting changes in the community via terminal restriction fragment length polymorphism (TRFLP). They observed slightly larger areas of a few of the largest TRFLP peaks (representing higher abundance of some common taxa) when viruses were reduced, and argued that this supports the 'phage kills winner' theory. However, the results of Waterbury \& Valois (1993) demonstrate that dominant culturable cyanobacteria are not heavily infected by local co- occurring viruses, suggesting that the 'phage kills winner' theory is in itself inadequate to describe viral infection dynamics in marine communities. Given these contrasting results, a further examination of the 'phage kills winner' theory was needed.

Since viral infection of bacteria is common and infection is a selective process, one would predict, a priori, that viruses would have an effect on overall bacterial community structure and diversity. To verify this assumption and to further understand the effects viruses have on marine bacterial communities, we incubated natural marine bacterial communities in seawater microcosms that had either significantly lower or significantly higher virus abundances compared to natural virus abundances. Bacterial community compositions were assayed at the beginning and end of each experiment to determine the effect of changes in viral abundance on bacterial communities. We used 2 whole-community fingerprint methods based upon ribosomal RNA and related genes, i.e. TRFLP (Avaniss-Aghajani et al. 1994) and automated rRNA intergenic spacer analysis (ARISA) (Borneman \& Triplett 1997, Fisher \& Triplett 1999), to rapidly assay changes in bacterial community composition. Our results indicate that viruses have mixed effects on different members of the microbial community, with some phylotypes increasing or decreasing in abundance, and other phylotypes showing no response to changes in viral abundances. The implications of these results and the effectivity of current molecular methods used to measure bacterial community diversity are discussed in the context of current theory.

\section{MATERIALS AND METHODS}

Sampling locations. Microcosms were established using seawater samples collected from 3 locations of opportunity: (1) El Porto Beach, California $\left(33^{\circ} 54^{\prime} \mathrm{N}\right.$, $118^{\circ} 25^{\prime} \mathrm{W}$ ), where, outside the breaker zone, samples were collected in acid-rinsed polycarbonate carboys and stored in a cooler during transport to the laboratory; (2) off the Wrigley Institute of Environmental Studies dock on Santa Catalina Island, California $\left(33^{\circ} 25^{\prime} \mathrm{N}, 118^{\circ} 28^{\prime} \mathrm{W}\right)$, where samples were collected in an acid-rinsed bucket and immediately transferred to a polycarbonate carboy that had also been rinsed with $1.2 \mathrm{~N} \mathrm{HCl}_{i}$ (3) at $5 \mathrm{~m}$ depth in the middle of San Pedro Channel $\left(33^{\circ} 33^{\prime} \mathrm{N}, 118^{\circ} 24^{\prime} \mathrm{W}\right)$, where seawater was collected in 101 Niskin bottles, transferred to acidrinsed polycarbonate carboys, and stored in a cooler during transport to the laboratory. Following collection, all samples were processed for use in the virusremoval experiments (VRE) or virus-addition experiments (VAE). 
Microcosm set-up. Virus-removal microcosms: Seawater from El Porto Beach and Santa Catalina Island was collected for the VRE in August 2001 and February 2002, respectively. Virus-removal microcosms were set up in a way similar to that described by Wilcox \& Fuhrman (1994), whereby natural prokaryotic communities were grown in the presence or absence of natural virus abundances. We vacuumfiltered $4 \mathrm{l}$ of seawater ( $<25 \mathrm{~cm} \mathrm{Hg}$ vacuum) through a $47 \mathrm{~mm} 0.22 \mu \mathrm{m}$ Type GV Durapore (Millipore) lowprotein binding filter to remove bacteria from the water. After removing the bacteria from the sample, half of the $<0.22 \mu \mathrm{m}$ bacteria-free filtrate was vacuum-filtered through a $0.02 \mu \mathrm{m} 47 \mathrm{~mm} \mathrm{Al}_{2} \mathrm{O}_{3}$ Anodisc (Whatman) filter to remove viruses from the water. The $<0.22 \mu \mathrm{m}$ bacteria-free filtrate and the $<0.02 \mu \mathrm{m}$ virus and bacteria-free filtrate were then used to fill duplicate $1 \mathrm{l}$ polycarbonate Erlenmeyer flasks which had been washed with $1.2 \mathrm{~N} \mathrm{HCl}$ and rinsed 3 times with appropriate filtrates prior to use. We filled 2 flasks with $585 \mathrm{ml}$ of the $<0.22 \mu \mathrm{m}$ bacteria-free filtrate and designated these 'control' treatments. Similarly, 2 additional flasks were filled with $585 \mathrm{ml}$ of the $<0.02 \mu \mathrm{m}$ virus and bacteria-free filtrate and designated 'virus-removal' treatments. Finally, each flask received an initial $15 \mathrm{ml}$ inoculum $(2.5 \% \mathrm{v} / \mathrm{v})$ of $<0.6 \mu \mathrm{m}$ grazer-free filtrate (described in the following paragraph) that contained bacteria and viruses. Upon completion of these steps, each experiment consisted of a total of 4 flasks: 2 control treatments containing $<0.22 \mu \mathrm{m}$ bacteria-free filtrate and $<0.6$ grazer-free filtrate, respectively, and 2 virus-removal treatments containing $<0.02 \mu \mathrm{m}$ bacteria and virus-free filtrate and $<0.6$ grazer-free filtrate, respectively.

The $<0.6 \mu \mathrm{m}$ grazer-free filtrate inoculum was prepared as follows: To remove grazers from the sample, approximately $500 \mathrm{ml}$ of the original, unfiltered seawater sample was gravity filtered twice through a $0.6 \mu \mathrm{m}$ Nuclepore filter. Two $50 \mathrm{ml}$ samples of the $<0.6 \mu \mathrm{m}$ grazer-free filtrate were collected for DNA analysis (see below), $50 \mathrm{ml}$ of $<0.6 \mu \mathrm{m}$ grazer-free filtrate was formalin preserved for bacteria and virus counts and the remaining $<0.6 \mu \mathrm{m}$ grazer-free filtrate was used as the initial inoculum described above. Following inoculation, the Catalina Island microcosms were incubated for $5 \mathrm{~d}$ in an outdoor, flow-through incubator at approximately $40 \%$ ambient light and in situ temperature $\left(15^{\circ} \mathrm{C}\right)$. The El Porto microcosms were incubated for $5 \mathrm{~d}$ in an unlit incubator also maintained at in situ temperature $\left(16^{\circ} \mathrm{C}\right)$.

Virus-addition microcosms: Seawater from San Pedro Channel and Santa Catalina Island was collected for the VAE in June and November of 2002 respectively. Virus-addition microcosms were con- ducted in 21 polycarbonate bottles that had been washed with $1.2 \mathrm{~N} \mathrm{HCl}$ and rinsed 3 times with seawater prior to use: 4 bottles received $1975 \mathrm{ml}$ of unfiltered seawater (containing phytoplankton), 2 treatment bottles received $25 \mathrm{ml}$ of live virus concentrate (see next paragraph) and 2 control bottles received $25 \mathrm{ml}$ of heat-killed virus concentrate to control for any possible DOM-addition effects.

Virus concentrates were prepared from seawater in several steps. Protists, metazoans and bacteria were removed from $20 \mathrm{l}$ of seawater by filtration through a $142 \mathrm{~mm} 0.8 \mu \mathrm{m}$ (nominal pore size) A/E glass-fiber filter (Pall Gelman) and $0.22 \mu \mathrm{m}$ Type GV Durapore filter (Millipore) in series. To concentrate the virussized fraction, the $<0.22 \mu \mathrm{m}$ filtrate was passed through an Amicon Spiral Wound cartridge filter (30000 Da molecular weight cut off, approximately $80 \%$ or higher recovery efficiency) (Millipore) according to manufacturer's recommendations. Briefly, the $<0.22 \mu \mathrm{m}$ filtrate was continuously pumped tangentially across a spiral wound cartridge filter under pressure $(2 \mathrm{kPa})$ until most of the seawater had passed through the membrane, thus concentrating the viruses into a small volume of seawater. Following concentration, the final volume of active virus concentrate was approximately $100 \mathrm{ml}$, half of which was killed with 3 cycles of heating to $100^{\circ} \mathrm{C}$ for $1 \mathrm{~min}$ followed immediately by cooling on ice for $1 \mathrm{~min}$. The live virus concentrate and heat killed virus concentrate were added to the appropriate microcosms within $10 \mathrm{~min}$ of concentration, resulting, on average, in a final concentration of viruses 3 times greater than ambient concentrations. VAE were incubated for $2 \mathrm{~d}$ in an outdoor, flow-through incubator at approximately $40 \%$ ambient light and in situ temperatures $\left(15^{\circ} \mathrm{C}\right)$.

Bacteria and virus enumeration. Samples for bacterial and viral abundances were taken daily from all experiments by removing $10 \mathrm{ml}$ of water from each bottle and preserving them with $0.02 \mu \mathrm{m}$ filtered formalin (1\% final volume). Duplicate bacteria and virus counts were obtained following staining of samples with SYBR Green I (Molecular Probes), as described by Noble \& Fuhrman (1998). Briefly, $3 \mathrm{ml}$ of seawater were filtered through a $0.02 \mu \mathrm{m}$ Anodisc filter. The filters were then placed on $100 \mu$ l of a solution of SYBR Green I (Molecular Probes) (1:2500 final concentration of original stock) and incubated for 15 min in the dark. Following incubation, the backs of the filters were dried gently with a Kimwipe tissue and mounted onto glass slides with $30 \mu \mathrm{l}$ of an antifade solution (Noble \& Fuhrman 1998). Slides were stored at $-20^{\circ} \mathrm{C}$ until counting.

Bacterial community analyses. DNA collection: Community DNA was collected from each microcosm 
at the beginning and end of all experiments as follows: Duplicate $50 \mathrm{ml}$ water samples were taken from all bottles. Each sample was divided in half and filtered with a light vacuum onto duplicate $25 \mathrm{~mm}$, $0.2 \mu \mathrm{m}$ Nuclepore filters. Following filtration, the Nuclepore filters were placed on a small drop of autoclaved, $0.02 \mu \mathrm{m}$ filtered deionized $\mathrm{H}_{2} \mathrm{O}$ in a $75 \mathrm{~mm}$ plastic petri dish. The petri dish was sealed and stored at $-80^{\circ} \mathrm{C}$ for subsequent community composition analysis. Bacterial community composition was assayed using TRFLP or ARISA. The El Porto VRE was analyzed using TRFLP, however, the resolution of TRFLP is coarser than ARISA, and subsequent experiments were thus analyzed with ARISA in an attempt to detect more subtle changes in community fingerprints.

PCR conditions: Bacterial community 16S rDNA or the intergenic spacer between the $16 \mathrm{~S}$ and $23 \mathrm{~S}$ ribosomal subunits was amplified from each experiment using a method similar to the filter PCR method described by Kirchman et al. (2001). Briefly, $1 / 8$ of the $25 \mathrm{~mm} 0.2 \mu \mathrm{m}$ Nuclepore filter was added to a $100 \mu \mathrm{l}$ PCR reaction that contained (final concentrations): $1 \mathrm{X}$ PCR buffer (Promega); $2.5 \mathrm{mM} \mathrm{MgCl}_{2}$ (Promega); $250 \mu \mathrm{mol}$ of each dNTP (Nucleotide Mix; Promega),

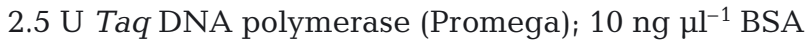
(Sigma 7030); and $0.4 \mu \mathrm{M}$ of each primer. The fluorescently labeled 27 forward (Escherichia coli numbering) ((TET)-5'-AGAGTTTGATCMTGGCTCAG-3') (Tm: $59.7^{\circ} \mathrm{C}$ ) primer and the universal 1392 reverse $\left(5^{\prime}\right.$ ACGGGCGGTGTGTRC-3') (Tm: $58.9^{\circ} \mathrm{C}$ ) primer were used in the TRFLP reactions (modeled after Lane et al. 1985).

The amounts of buffer, $\mathrm{MgCl}_{2}$, $\mathrm{dNTPs}$ and primers in the ARISA PCR reactions were identical to those in the TRFLP reactions; however, the forward primer was the 16S universal 1392 (5'-GYACACACCGCCCGT-3') (Tm: $60.3^{\circ} \mathrm{C}$ ) primer and the reverse primer was the fluorescently labeled 23S bacterial 130((TET)-5'GGGTTBCCCCATTCRG-3') (Tm: $59.7^{\circ} \mathrm{C}$ ) primer (Borneman \& Triplett 1997). All PCR reactions were amplified in a Thermolyne thermocycler beginning with an initial 2 min hotstart at $95^{\circ} \mathrm{C}$ followed by 30 cycles of the following: denaturing, $45 \mathrm{~s}$ at $95^{\circ} \mathrm{C}$, annealing, $45 \mathrm{~s}$ at $55^{\circ} \mathrm{C}$, and extending, $1.5 \mathrm{~min}$ at $72^{\circ} \mathrm{C}$. PCR reactions finished with a $5 \mathrm{~min}$ final extension at $72^{\circ} \mathrm{C}$. In order to obtain sufficient amounts of DNA, PCR reactions were performed in duplicate and then combined with Qiagen columns as follows: Following amplification, TRFLP PCR products were loaded into a $1.0 \%$ agarose (GTG Nusieve Agarose; BioWhittaker Molecular Applications) gel, run for $1.2 \mathrm{~h}$ at $100 \mathrm{~V}$, stained with SYBR gold (Molecular Probes) and visualized. TRFLP PCR products of the correct size (1392 bp) were excised, and the DNA was extracted using a Qiagen MinElute gel elution kit (\#28604). Following amplification, ARISA PCR products were cleaned and concentrated using a Qiagen MinElute PCR purification kit (\#28004).

TRFLP restriction digests: Duplicate TRFLP PCR products were digested from the El Porto VRE as follows: $50 \mathrm{ng}$ of band-isolated PCR product was added to a $20 \mu \mathrm{l}$ reaction containing $0.5 \mathrm{U}$ of the restriction enzyme HhaI $\left(\mathrm{GCG}^{\wedge} \mathrm{C}\right)$ (New England Biolab, NEB), $1 \mathrm{X}$ NEB Buffer \#4 and $1 \mathrm{ng}^{-1} \mathrm{l}^{-1}$ NEB 100× BSA. Reactions were digested at $37^{\circ} \mathrm{C}$ for $18 \mathrm{~h}$ and then stored at $-20^{\circ} \mathrm{C}$ until analysis. Amplified ARISA PCR products

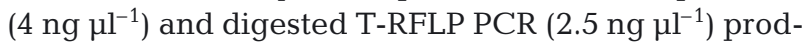
ucts were run in duplicate for $5 \mathrm{~h}$ on an ABI 377XL automated sequencer. Each sample also contained $1.5 \mathrm{\mu l}$ of either the 500 or $2500 \mathrm{bp}$ Tamra-labeled internal standard (ABI Genescan). The resulting electropherograms were analyzed with Genescan software (2000). ARISA products are not subjected to restriction digestion.

Data analysis: TRFLP and ARISA peaks greater that 20 relative fluorescent units (ca. 5 times above background noise, minimum peak detection limit of approximately $5 \mathrm{pg}$ ) were extracted from the electropherograms using Genescan software and were then transferred to Microsoft Excel for subsequent analysis. Duplicate Genescan readings of the same sample (same bottle, same treatment) were aligned by size, and all non-replicated peaks were removed from the data set. The total area under the curve was then summed and the relative percentage of each phylotype was determined by dividing the integrated area beneath individual fragments by the total area under the curve (similar to the method of Gonzalez et al. 2000). Replicated fragments between duplicate treatments (different bottles, same treatment) were then averaged, and the results were expressed as the mean percentage within a treatment $\pm 1 \mathrm{SE}$ of the mean. After performing the above calculations, specific differences in percent area between virus treatments and initial and final time points were tested for significance using a Student's $t$-test In addition, whole community similarity matrices were calculated from the original ABI Genescan files for each experiment using the TRFLP tool available on the RDP II website http://rdp.cme.msu.edu/html/ (Maidak et al. 2001). Briefly, this algorithm calculates a similarity value based upon the total shared number of peaks in both treatments divided by the total number of fragments in both fingerprints. Default sizing errors were input into the algorithm while matching fingerprints except for TRFLP patterns the shortest fragment considered was $50 \mathrm{bp}$ while for ARISA the shortest fragment considered was $300 \mathrm{bp}$. 


\section{RESULTS}

\section{Virus and bacteria counts \\ Virus-removal experiments}

Bacteria counts from the VRE were similar, whether viruses had been removed or not (Fig. 1A). Bacterial growth rates (calculated from changes in cell counts over time during the log phase of growth) ranged between 1.5 and $2 \mathrm{~d}^{-1}$, translating to a total of 9 or less generations during the $5 \mathrm{~d}$ experiments. Virus counts from the VRE fluctuated following the initial filtration and setting up of the microcosms, but then remained relatively constant during the latter half of the experiment (Fig. 1B). Virus abundance in the virus-removal microcosms was approximately $2.5 \%$ of the total virus abundance in control microcosms throughout the entire experiment.

\section{Virus-addition experiments}

Bacterial abundances in the VAE were similar in magnitude for both experiments, regardless of virus treatment (Fig. 1C). Virus addition microcosms con- tained both viruses and grazers, and had slightly lower cell counts than those in the virus-removal microcosm from the Catalina Island experiment, which had no grazers. Typical heterotrophic bacterial growth rates determined by thymidine and leucine incorporation from the middle of San Pedro Channel are between 0.1 and $0.3 \mathrm{~d}^{-1}$ for the time of year when the water was obtained (unpubl. data). These rates are lower than community growth rates at the other locations sampled during these experiments and translate to approximately 2 or less generations during the $2 \mathrm{~d}$ experiment. Virus counts from VAE were nearly constant throughout the experiment (Fig. 1D). Virus abundance in the virus-addition microcosms remained approximately $300 \%$ above virus abundance in control microcosms for the duration of both experiments.

\section{Community composition analyses}

Plotting all community fingerprints on a rankabundance graph revealed between 13 and 30 phylotypes in each experiment that individually comprised $>1 \%$ of the total fingerprint area (Fig. 2). In using these results to compare treatments, it is important to note that the estimate of the total number of phylo-
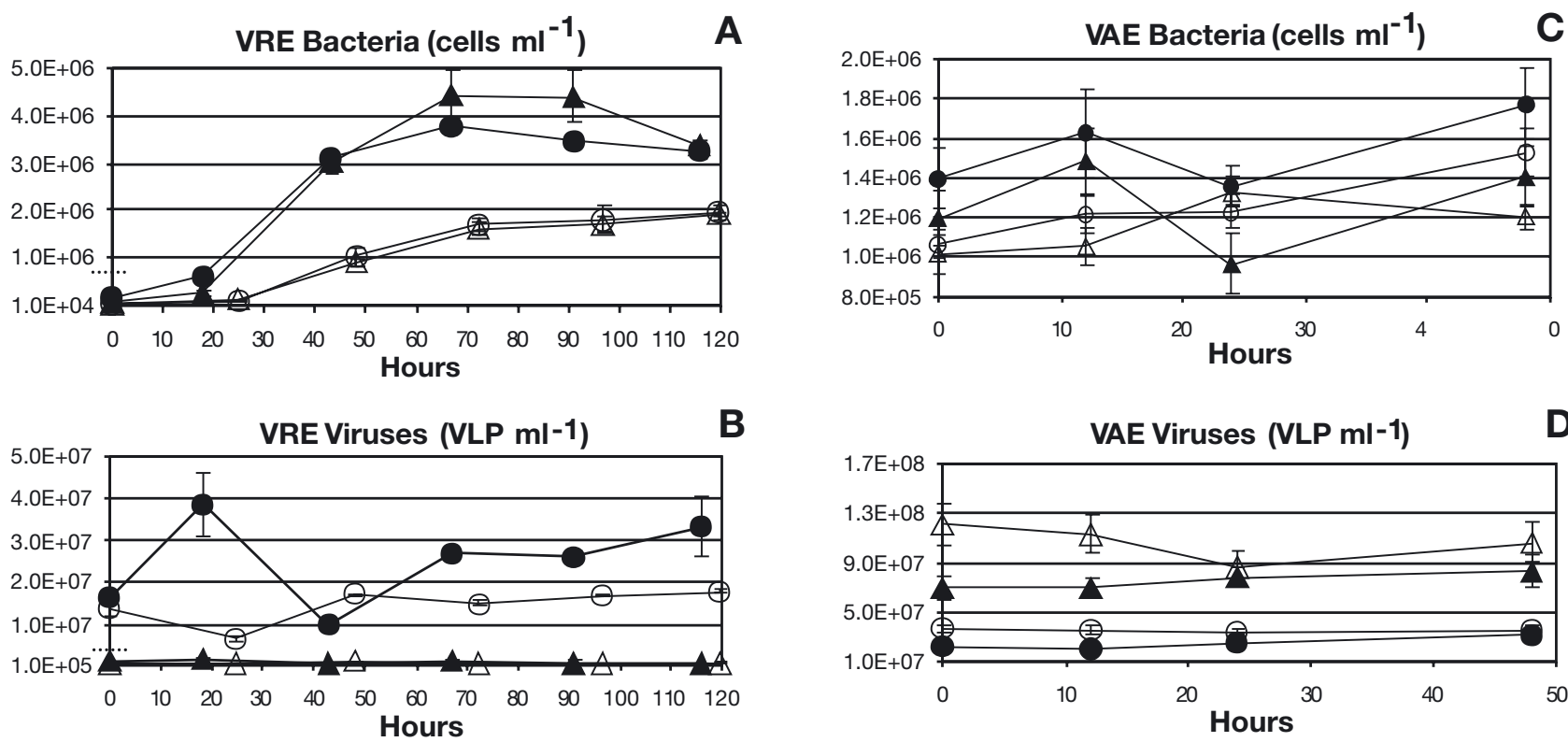

B
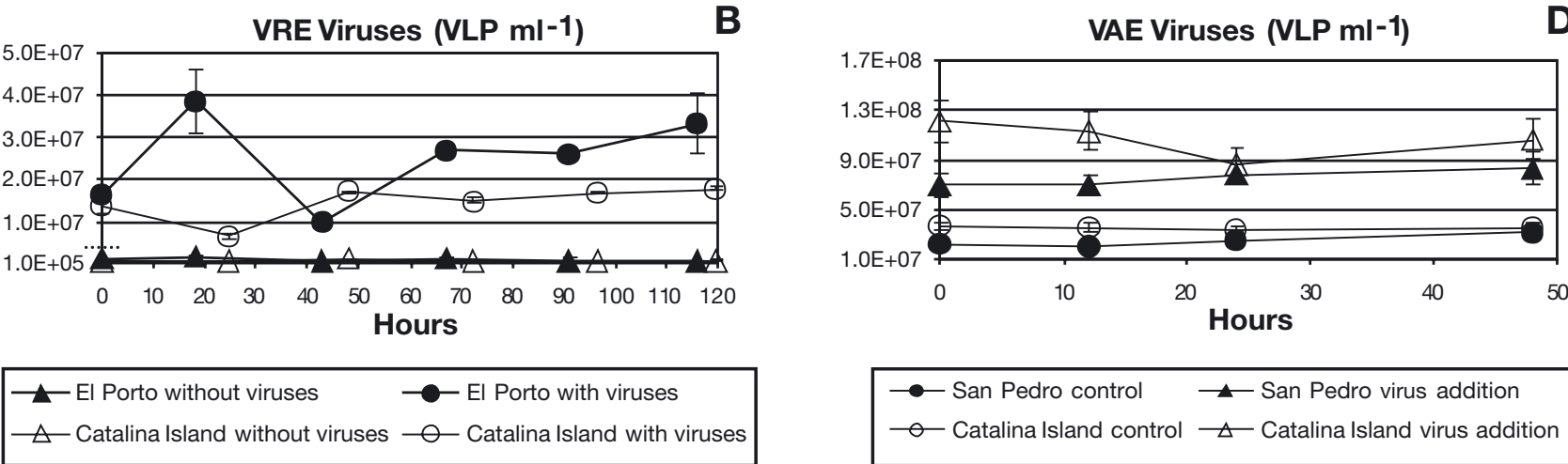

Fig. 1. (A) Bacteria counts (cells $\mathrm{ml}^{-1}$ ) and (B) virus counts (virus like particles, VLP $\mathrm{ml}^{-1}$ ) from the virus-removal experiments (VRE). (C) Bacteria counts (cells ml ${ }^{-1}$ ) and (D) virus counts (VLP ml${ }^{-1}$ ) from the virus-addition experiments (VAE). Error bars $=$ \pm 1 SE. Dotted line on ordinates in (A) and (B) indicates scale break. Virus abundance was 2.5 and $300 \%$ ambient abundance in VRE and VAE, respectively 


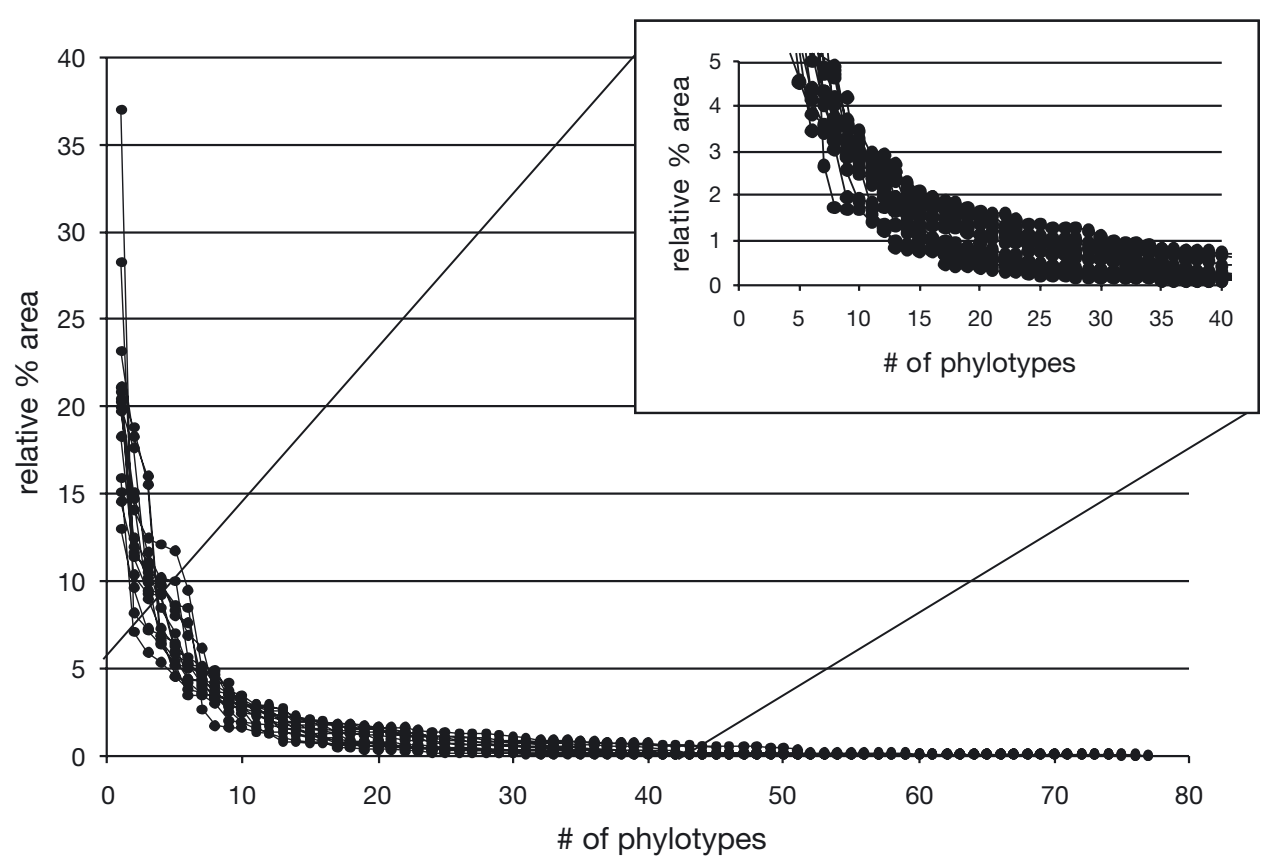

Fig. 2. Rank-abundance distribution of fingerprints obtained in this study based on percentage area $(\mathrm{N}=$ 15). Fingerprints contained between 13 and 30 phylotypes that individually comprised $1 \%$ or more of the total community area (inset), with many more individual phylotypes comprising less than $1 \%$ of the total fingerprint area types (including the most minor components) within a treatment would be influenced by the amount of DNA used for analysis, which is an artifact of all community fingerprint methodologies. In community fingerprinting, the total number of phylotypes observed increases as the amount of DNA in the analysis increases because, as more DNA is added, the smaller peaks have a greater chance of exceeding the background threshold of detection. Since the amount of DNA used in each small-volume 'filter PCR' reaction cannot be standardized, comparison of overall diversity based on total number of phylotypes would be misleading, and thus was not calculated. Instead, our analysis focused on phylotypes individually comprising $>1 \%$ of the total fingerprint area. This cutoff was chosen because most $(91.3 \pm 0.7 \%)$ of the total fingerprint area was associated with peaks comprising $>1 \%$ of the total community area, and because larger peaks are less affected than smaller peaks by the potential artifacts mentioned above. The average similarities (based on presence/absence) between fingerprints at the end of each experiment are listed in Table 1. In all experiments, replicate treatments were more similar to each other than virus treatments were to the controls. Furthermore, all fingerprints at the end of the experiments were more similar to each other than they were to the initial community fingerprint. Individual experiment results are discussed below, but because of the minor procedural differences mentioned above, experiments from different locations are not directly compared to each other.

Table 1. Mean fingerprint similarity based on whole-community comparisons; indices calculated using the TRFLP tool on the Ribosomal Database Project (RDP) website (http://rdp.cme.msu.edu/html). Students $t$-test p-values: A vs B = $0.052 ; \mathrm{A}$ vs C $=0.012$

\begin{tabular}{|llccc|}
\hline $\begin{array}{l}\text { Expt type and } \\
\text { fingerprint method }\end{array}$ & $\begin{array}{c}\text { Location } \\
\text { (California) }\end{array}$ & $\begin{array}{c}\text { (A) Within replicates, } \\
\text { Time }_{\text {final }}\end{array}$ & $\begin{array}{c}\text { (B) Between treatments, } \\
\text { Time }_{\text {final }}\end{array}$ & $\begin{array}{c}\text { (C) Between Time } \\
\text { and }_{\text {initial }}\end{array}$ \\
\hline Virus addition, ARISA & Catalina Island & 0.909 & 0.812 & 0.792 \\
& San Pedro Channel & 0.844 & 0.757 & 0.603 \\
Virus removal, ARISA & Catalina Island & 0.870 & 0.856 & 0.717 \\
Virus removal, TRFLP & Catalina Island & 0.718 & 0.712 & 0.674 \\
Mean & El Porto Beach & 0.830 & 0.697 & 0.693 \\
SE & & 0.834 & 0.767 & 0.696 \\
\end{tabular}


Fig. 3. Virus-removal experiment (VRE) data from (A) El Porto Beach TRFLP analysis and (B) Catalina Island ARISA analysis. Peaks represent average relative \% area of a fragment within a treatment. Error bars are $\pm 1 \mathrm{SE}$ of the average \% area determined from 2 replicate treatments. Only fragments with a relative area $>1 \%$ in any of the treatments are shown. +: significant difference in phylotype magnitude between virus treatment and control; *: significant difference in phylotype magnitude between initial and final fingerprint
El Porto Beach VRE TRFLP

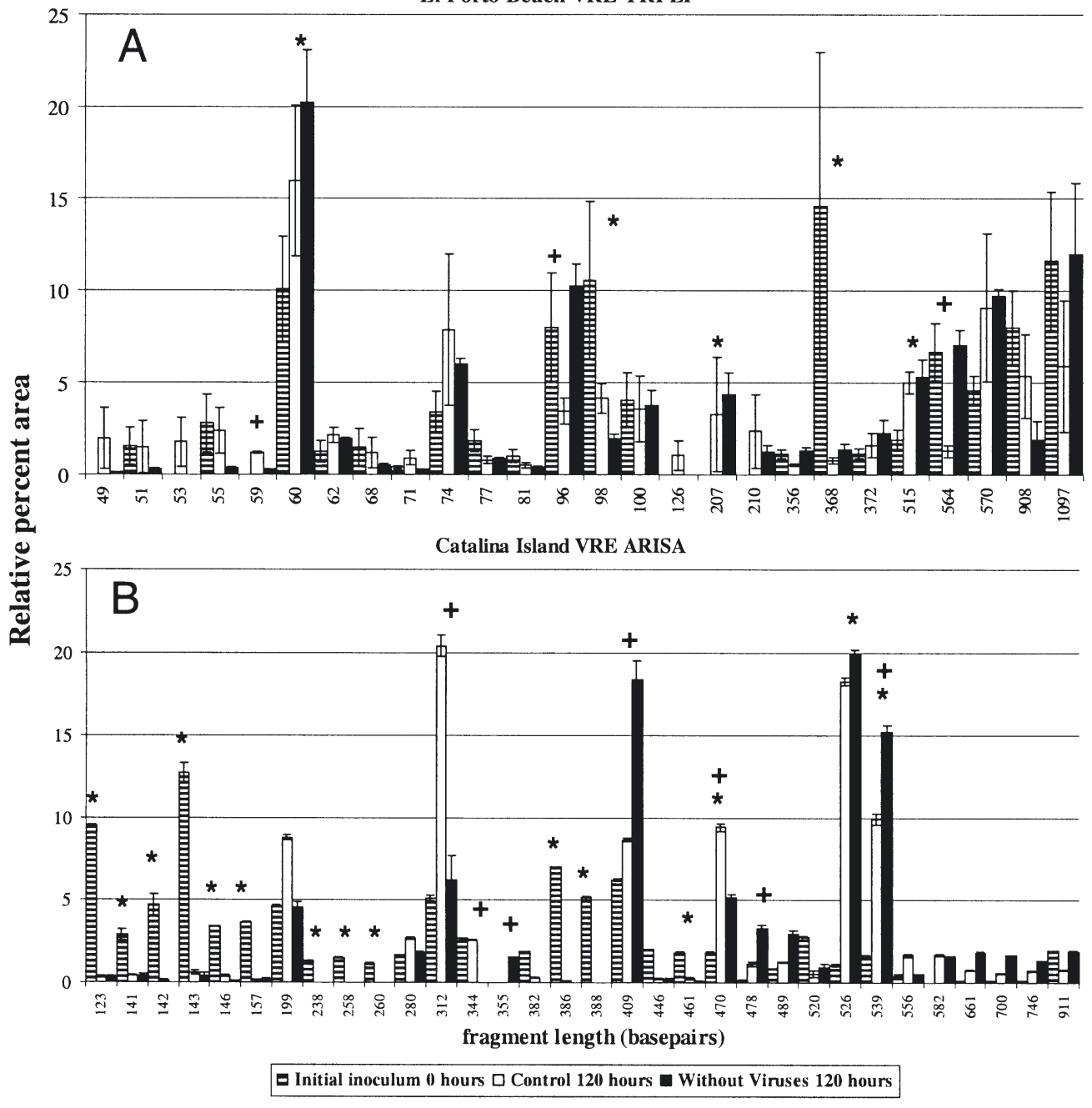

Virus-removal experiments

El Porto Beach: TRFLP fingerprints from the El Porto Beach experiment revealed small differences in community fingerprints between virus treatments as well as larger changes between the initial and final community fingerprints (Fig. 3A). Two-tailed Student's $t$-tests were used to determine if selected fragments from the virus treatments were significantly different between the initial inoculum and the final control fingerprints. The $t$-test results indicated that 3 fragments were significantly different between the virus treatment and the control at the end of the experiment, and 5 fragments were significantly different between the initial inoculum fingerprint and the final fingerprints regardless of the virus treatment. No TRFLP fragment was significantly different from both the initial and final community or between virus treatments at the end of this experiment.
Santa Catalina Island: Small changes in the TRFLP (data not shown) and ARISA fingerprints (Fig. 3B) were observed following the removal of viruses from the Santa Catalina Island experiment. Statistical analysis of TRFLP results revealed that 2 fragments were significantly different between the virus treatment and the control, while 5 fragments changed significantly regardless of virus treatment. Reanalysis of the same sample using the more discerning ARISA fingerprinting method revealed that 7 fragments were significantly different between the virus treatment and the control at the end of the experiment while 15 fragments were significantly different at the end of the experiment regardless of the virus abundance. Finally, 2 ARISA fragments were significantly different from both the control treatment and between virus treatments. The 470 VRE fragment was lower than its corresponding control fragment while the 539 VRE fragment was higher than its corresponding control fragment. 


\section{Virus-addition experiments}

Santa Catalina Island: Analysis of ARISA results from this experiment revealed few differences in the community fingerprints between virus and control treatments (Fig. 4A). Following $2 \mathrm{~d}$ of incubation, similar changes in the community fingerprints were observed irrespective of virus abundance. Statistical analysis of individual fragments revealed that there were no fragments that were significantly different between treatments, but there were 2 fragments that were significantly different from their initial relative percentages irrespective of virus abundance.

San Pedro Channel: Analysis of ARISA fingerprints from the San Pedro Channel experiment revealed few differences in community fingerprints between treatments (Fig. 4B). However, bacteria community fingerprints shifted similarly in both treatments regardless of virus abundance, following $2 \mathrm{~d}$ of incubation. Statisti- cal analysis of individual fragments also found no significant virus effect on the fingerprint; however, at the end of the experiment, 6 fragments had percentage areas that were significantly different than their initial percentage area, regardless of the virus treatment.

\section{DISCUSSION}

Small shifts in bacterial community fingerprints were observed within days when virus abundance was either reduced or increased relative to initial abundances, although only the VRE showed statistically significant changes in response to virus treatments. The difference between VRE and VAE results probably partially reflects the fact that the VRE had a strong growth phase and spanned up to 9 generations, while the VAE probably spanned only 1 or 2 generations (averaging the generation times among all bacteria).

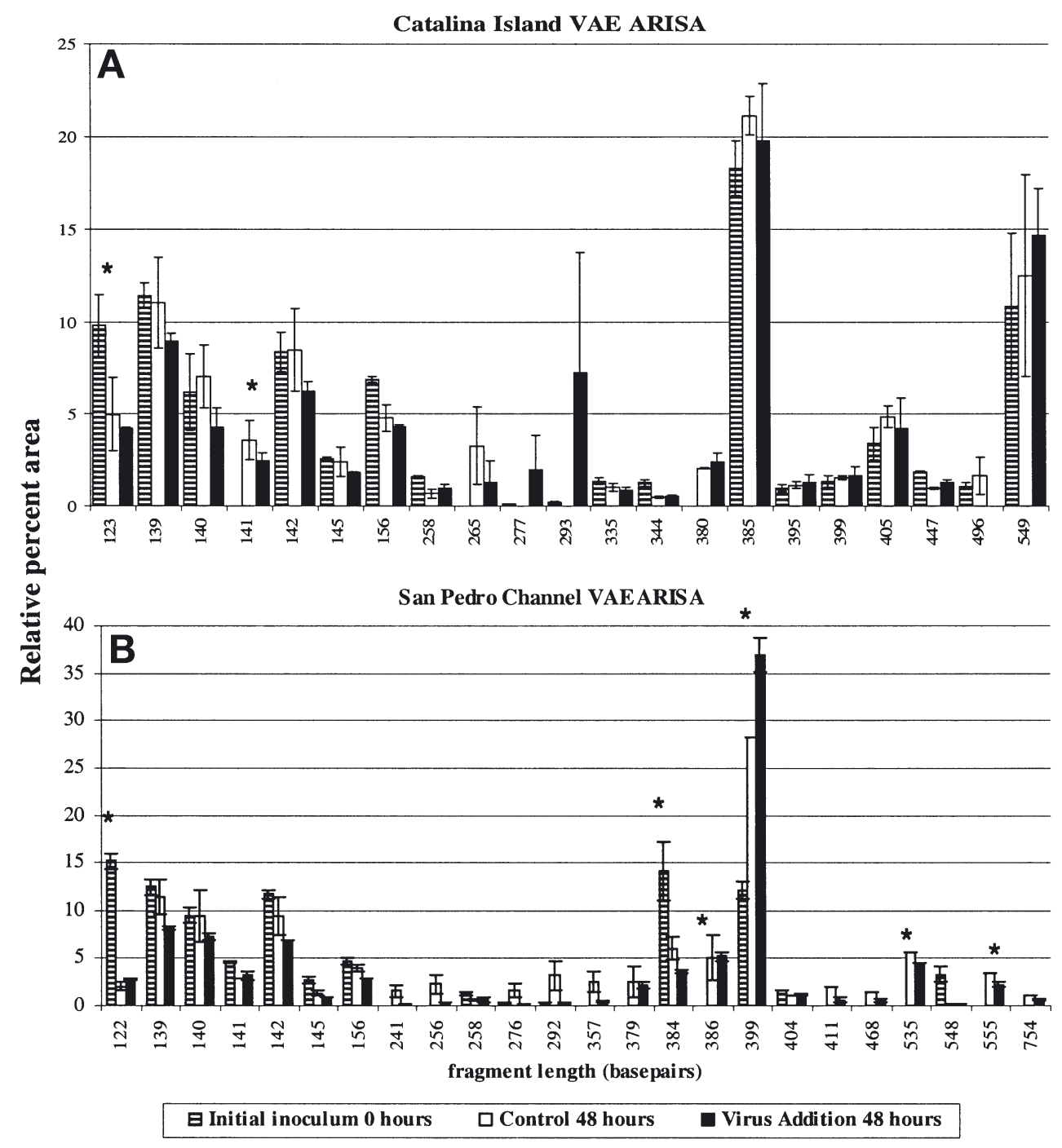

Fig. 4. Virus-addition experiment (VAE) data from (A) Catalina Island ARISA analysis and (B) San Pedro Channel ARISA analysis. Further details as in Fig. 3. No significant virus treatment effects were observed; *: significant difference in phylotype magnitudes between initial and final fingerprint 
The relative percentages of some phylotypes increased or decreased significantly between treatments, suggesting that altering the viral abundance had a mixed effect on the overall bacterial community fingerprint. It is not known how representative relative peak areas in TRFLP and ARISA fingerprints are of relative in situ bacterial abundances. PCR artifacts, such as the disproportionate representation of minor constituents after many amplification cycles and variation between results with different genes and primer pairs (Suzuki \& Giovannoni 1996, Lueders \& Friedrich 2003), most likely preclude direct correlation of peak area and in situ abundance. However, we have reason to believe they are related, although possibly not directly proportional. We found that the molecular fingerprints in this experiment were highly reproducible (Table 1: A), as they have been elsewhere (Fisher et al. 2000), and a recent report suggests that TRFLP with 16S rRNA genes can yield results proportional to bacterial abundances (Lueders \& Friedrich 2003). Given the high reproducibility between replicate, independent fingerprints, changes in an individual phylotype's percentage were interpreted to reflect a change in a phylotype's abundance, and any significant changes between percentage area of individual phylotypes were judged to be due to real changes in the bacterial community. Making the above assumptions also allowed us to look for statistically significant differences between the percentage area comprised by individual phylotypes as well as for significant changes between community fingerprints as a whole. Note that if we had limited the comparisons to calculating similarity matrices based on the shared number of phylotypes between fingerprints (presence/absence), there would have been fewer changes. However, even with such a demanding criterion as presence/absence, some such changes occurred as a result of virus manipulation (Table 1: B).

At the end of all experiments, fingerprints from replicate bottles were more similar to each other than virus treatments were to control treatments $(p=0.05)$, suggesting that viruses did play some part in structuring the fingerprints. In addition to virus effects, our manipulation (filtration, dilution, and grazer removal in the VRE) and incubation of the seawater in the laboratory for 2 or $5 \mathrm{~d}$ had an effect on the bacterial community fingerprints, and this tended to be the largest effect we observed. Fingerprint similarity scores were lowest when initial community fingerprints were compared to final community fingerprints (Table 1: C). At the end of all experiments, fingerprints from replicate bottles were more similar to each other than initial fingerprints were to final fingerprints $(p=0.01)$, confirming that our manipulation and incubation of seawater significantly altered the microbial community fingerprint.
It is interesting that in the one instance (Catalina Island virus-removal experiment) where we compared TRFLP and ARISA for the same sample, the ARISA fingerprints showed more significant differences between virus treatments. This may be because ARISA has the potential to be more discerning between close relatives due to the hypervariability of the intergenic spacer region that is assayed; however, both methods tended to result in similar numbers of taxa or 'operational taxonomic units' (OTU) in these experiments. We should also note that although it is possible to tentatively identify the OTU in the TRFLP fingerprints (e.g. Gonzalez et al. 2000), during this study we did not have clone libraries that could ideally be used for such tentative identifications for TRFLP or ARISA.

In all experiments, the total bacterial cell counts were similar between the virus and control treatments regardless of virus abundance. This suggests that viruses were not limiting the growth of the overall bacteria community in these experiments. However, the early fluctuations in the virus counts observed in the VRE and the consistency of virus abundance in the VAE both suggest a highly active virus community that was maintained by lytic infection during these experiments. Had no lytic infection occurred in our experiments, virus abundances would have decreased rapidly due to viral decay (Noble \& Fuhrman 2000). Finally, it should be noted that virus abundance in the virus-removal control treatments remained about $2.5 \%$ or less of ambient virus abundance for the duration of the experiments. This is consistent with earlier findings by Wilcox \& Fuhrman (1994), and supports the conclusion that lysogeny was not an important source of virus production in these VRE.

The results from this and earlier studies (Fuhrman \& Schwalbach 2003) raise interesting questions about the way in which we regard viruses and their potential control of bacterial community composition. In the 'phage kills winner' hypothesis, viruses are thought to help control the population size of bacteria that are successful competitors for resources and thus become abundant (Fuhrman \& Suttle 1993, Thingstad \& Lignell 1997). Implicit in this hypothesis is the idea that all members of a given bacterial type are sensitive to infection. However, the results presented here, whereby changes in virus abundance appeared to have little dramatic effect on community composition on time scales of 2 to $5 \mathrm{~d}$, do not seem fully consistent with that concept. This could indicate that the bacteria are resistant to infection, as suggested by Waterbury \& Valois (1993), but the observed high virus abundance (and previous evidence about turnover rates; Noble \& Fuhrman 2000) implies a continuous and significant source of viruses, and extensive field data have been interpreted as indicating that on the order of 10 to $40 \%$ of the bacteria are 
infected at a given time (reviewed by Fuhrman 1999). To reconcile these disparate observations, we suggest that perhaps there is a relatively stable coexistence between dominant phylotypes and their viruses, and that each phylotype may exist simultaneously in both a virus-sensitive and virus-resistant form. This would be consistent with the results of chemostat studies (Levin et al. 1977, Lenski 1988, Middleboe et al. 2001) and culture work (Waterbury \& Valois 1993) wherein the authors have reported that viruses survive by infecting less-abundant, sensitive cells in the community, despite the majority of the cells being resistant to viral infection. However, it remains to be determined which members of the microbial community are supporting the high virus production rates observed in the ocean.

As only a handful of significant treatment effects were observed in the $5 \mathrm{~d}$ VRE (Fig. 3) and no significant treatment effects were observed in the $2 \mathrm{~d}$ VAE (Fig. 4) it would seem that viruses did not play a strong role in structuring the bacterial community fingerprints on time-scales of 2 to $5 \mathrm{~d}$. This conclusion is consistent with that of Middleboe et al. (2001), who found that viruses initially influenced the strains of bacteria in a chemostat, but that over longer time scales of days, bacterial communities were structured primarily by interspecific competition among resistant strains. It is still not clear if we can directly apply the results of such highly simplified experiments to complex natural ecosystems, since confounding factors such as fluctuating resources, multiple species interactions, grazing effects, allelopathy, and the cost of resistance may also be very important. The ecological consequences of virus infection are still unknown at this time, and it is possible that the small immediate effects of viral infection observed in these experiments could be significantly amplified over longer time scales of months or years. More work will be needed before the long-term effects of viral infection on community function and composition is wholly understood.

Acknowledgements. We would like to thank the crews of the RV 'Seawatch' and the RV 'Point Sur' for assistance with sample collection, and the Wrigley Institute of Environmental Science. This work was supported by NSF grants OCE 9906989, OCE 0084231 and OCE 0241723 to J.A.F. I.H. was supported by a USC Sea Grant traineeship during this study.

\section{LITERATURE CITED}

Avaniss-Aghajani E, Jones K, Chapman D, Brunk C (1994) A molecular technique for identification of bacteria using small subunit ribosomal RNA sequences. Biotechniques 17:144-149

Bohannan BJM, Lenski R (2000) Linking genetic change to community evolution: insights from studies of bacteria and bacteriophage. Ecol Lett 3:362-377
Borneman J, Triplett EW (1997) Molecular microbial diversity in soils from Eastern Amazonia: evidence for unusual microorganisms and microbial population shifts associated with deforestation. Appl Environ Microbiol 63: 2647-2653

Bratbak G, Thingstad F, Heldal M (1994) Viruses and the microbial loop. Microb Ecol 28:209-221

Bratbak G, Heldal M, Thingstad TF, Tuomi P (1996) Dynamics of virus abundance in coastal seawater. FEMS Microbiol Ecol 19:263-269

Bratbak G, Jacobsen A, Heldal M (1998) Viral lysis of Phaeocystis pouchetti and bacterial secondary production. Aquat Microb Ecol 16:11-16

Fisher MM, Triplett EW (1999) Automated approach to ribosomal intergenic spacer analysis of microbial diversity and its application to freshwater bacterial communities. Appl Environ Microbiol 65:4630-4636

Fisher MM, Klug JL, Lauster G, Newton M, Triplett EW (2000) Effects of resources and trophic interactions on freshwater bacterioplankton diversity. Microb Ecol 40:125-138

Fuhrman JA (1992) Bacterioplankton roles in cycling of organic matter: the microbial food web. In: Falkowski PG, Woodhead AD (eds) Primary productivity and biogeochemical cycles in the sea. Plenum Press, New York, p 361-383

Fuhrman JA (1999) Marine viruses: biogeochemical and ecological effects. Nature 399:541-548

Fuhrman JA, Noble RT (1995) Viruses and protists cause similar bacterial mortality in coastal seawater. Limnol Oceanogr 40:1236-1242

Fuhrman JA, Schwalbach MS (2003) Viral influence on aquatic bacterial communities. Biol Bull 204:192-195

Fuhrman JA, Suttle C (1993) Viruses in marine planktonic systems. Oceanography 6:51-63

Gobler CJ, Hutchins DA, Fisher NS, Cosper EM, SanudoWilhelmy SA (1997) Release and bioavailability of C, N, P, Se, and Fe following viral lysis of a marine chrysophyte. Limnol Oceanogr 42:1492-1504

Gonzalez JM, Simo R, Massana R, Covert JS, Casamayor EO, Pedros-Alio C, Moran MA (2000) Bacterial community structure associated with a dimethylsulfoniopropionateproducing North Atlantic algal bloom. Appl Environ Microbiol 66:4237-4246

Guixa-Boixereu N, Lysnes K, Pedros-Alio C (1999) Viral lysis and bacterivory during a phytoplankton bloom in a coastal water microcosm. Appl Environ Microbiol 65:1949-1958

Hennes KP, Simon M (1995) Significance of bacteriophages for controlling bacterioplankton growth in a mesotrophic lake. Appl Environ Microbiol 61:333-340

Hennes KP, Suttle CA, Chan AM (1995) Fluorescently labeled virus probes show that natural virus populations can control the structure of microbial communities. Appl Environ Microbiol 61:3623-3627

Kirchman DL, Yu L, Fuchs BM, Amann R (2001) Structure of bacterial communities in aquatic systems as revealed by filter PCR. Aquat Microb Ecol 26:13-22

Lane DJ, Pace B, Olsen G, Stahl DA, Sogin ML, Pace NR (1985) Rapid determination of 16s rRNA sequences for phylogenetic analysis. Proc Natl Acad Sci USA 82: 6955-6959

Lenski RE (1988) Dynamics of interactions between bacteria and virulent bacteriophage. Adv Microb Ecol 10:1-44

Levin BR, Stewart FM, Chao L (1977) Resource limited growth, competition and predation - a model and experimental studies with bacteria and bacteriophage. Am Nat 111:3-24

Lueders T, Friedrich MW (2003) Evaluation of PCR amplification bias by terminal restriction fragment length polymor- 
phism analysis of small-subunit rRNA and mcrA genes by using defined template mixtures of methanogenic pure cultures and soil DNA extracts. Appl Environ Microbiol 69:320-326

Maidak BL, Cole JR, Lilburn TG, Parker CT Jr and 6 others (2001) The RDP-II (Ribosomal Database Project). Nucleic Acids Res 29:173-174

Middelboe M, Lyck PG (2002) Regeneration of dissolved organic matter by viral lysis in marine microbial communities. Aquat Microb Ecol 27:187-194

Middelboe M, Hagström Å, Blackburn N, Sinn B and 5 others (2001) Effects of bacteriophages on the population dynamics of four strains of pelagic marine bacteria. Microb Ecol 42:395-406

Moebus K (1996) Marine bacteriophage reproduction under nutrient limited growth of host bacteria. 2. Investigation with a phage-host system (H3:H3/1). Mar Ecol Prog Ser 144:13-22

Noble RT, Fuhrman JA (1998) Use of SYBR Green I for rapid epifluorescent counts of marine viruses and bacteria. Aquat Microb Ecol 14:113-118

Noble RT, Fuhrman JA (2000) Rapid virus production and removal as measured with fluorescently labeled viruses as tracers. Appl Environ Microb 66(9):3790-3797

Proctor LM, Fuhrman JA (1990) Viral mortality of marinebacteria and cyanobacteria. Nature 343:60-62

Šimek K, Pernthaler J, Weinbauer MG, Hornak K, Dolan JR, Nedoma J, Masin M, Amann R (2001) Changes in bacterial community composition and dynamics and viral mor-

Editorial responsibility: Curtis Suttle,

Vancouver, Canada tality rates associated with enhanced flagellate grazing in a mesoeutrophic reservoir. Appl Environ Microbiol 67: 2723-2733

Steward GF, Smith DC, Azam F (1996) Abundance and production of bacteria and viruses in the Bering and Chukchi Sea. Mar Ecol Prog Ser 131:287-300

Suzuki MT, Giovannoni SJ (1996) Bias caused by template annealing in the amplification of mixtures of 16S rRNA genes by PCR. Appl Environ Microbiol 62:625-630

Thingstad TF (2000) Elements of theory for the mechanisms controlling abundance, diversity and biogeochemical role of lytic bacterial viruses in aquatic systems. Limnol Oceanogr 45:1320-1328

Thingstad TF, Lignell R (1997) Theoretical models for the control of bacterial growth rate, abundance, diversity and carbon demand. Aquat Microb Ecol 13:19-27

Waterbury JB, Valois FW (1993) Resistance to co-occurring phages enables marine Synechococcus communities to coexist with cyanophages abundant in seawater. Appl Environ Microbiol 59:3393-3399

Weinbauer MG, Peduzzi P (1995) Effect of virus-rich high molecular weight concentrates of seawater on the dynamics of dissolved amino acids and carbohydrates. Mar Ecol Prog Ser 127:245-253

Wilcox RM, Fuhrman JA (1994) Bacterial viruses in coastal seawater: lytic rather than lysogenic production. Mar Ecol Prog Ser 114:35-45

Wommack EK, Colwell RR (2000) Virioplankton: viruses in aquatic ecosystems. Microbiol Mol Biol Rev 64:69-114

Submitted: April 5, 2003; Accepted: October 3, 2003

Proofs received from author(s): January 26, 2004 